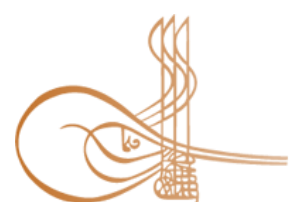

www.turkishstudies.net/religion
Turkish Studies - Comparative Religious Studies

eISSN: 2667-5544

Research Article / Araştırma Makalesi

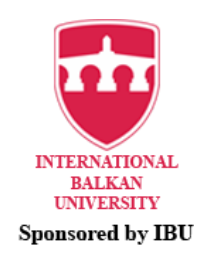

Sponsored by IBU

\title{
Şeyh Ahî Dâ‘î Fütüvvetnâmesi’nde Ahlâkî Değerler
}

\author{
Moral Values in Sheikh Ahî Dâ '̂̀'s Fütüvvetnâme
}

\author{
Mehmet Şahin* - Şeref Göküş**
}

\begin{abstract}
The works in the form of nizamname, which are about the morality, rule and power of futuwwa, were called fütüvvet-name. Fütüvvet-names are the handbooks of Turkish-Islamic guild which discussed the subject of personal, social and business ethics to create a virtuous society and were applied by the craftsmen and craftsmen unions in Anatolia from 13th century and 19th century. These are books that adopt the principles of chastity, justice, goodwill and wisdom in individual and vocational education and teach values such as truth, generosity, humility, repentance, safety, advice and loyalty. These moral values were taught by the TurkishIslamic guild, an institution of non-formal education. Thus, efforts have been made to ensure social unity and solidarity and to create a common culture. In this sense, Arabic, Persian and Turkish fütüvvet-names were written. These fütüvvet-names and the studies on it have been shown as far as possible. This study aims to examine the moral values in the futuristic version of Sheikh Ahî Dâ'î et-Tarsûsi, who was understood to have lived in the late 14th and early 15th centuries, among the most sizable fütüvvet-names. As a result of the research prepared with the method of document analysis, it was seen that the work of Sheikh Ahî Dâ'î was close to Old Anatolian Turkish in terms of language characteristics and the moral values in fütüvvet-name were similar to other fütüvvet-names and the common themes overlapped. In Ahî Dâ'i Fütvvet-name, there are both the principles of vocational education, moral values and stages of religious education. The principles of belief, morality, knowledge, and art-centred in the fütüvvet-name were put into practice by the organization of the Turkish-Islamic Guild. Based on Ahî Dâ'‘'’s work, It is seen that there is a goal to raise an individual who is developed in all respects with his knowledge, belief, profession, morality and literature.
\end{abstract}

Structured Abstract: Futuwwa is a conception which was derived from the Arabic word feta meaning young, valiant, generous, hero, young servant, lad and powerful. While the words "ahi(Turkish-Islamic guild), valiant, alp and soldier" are used as the equivalent of the word feta, the words "fütüvvet-dar" (valiant) and "civanmerd" (brave) were preferred in Persian. The word "Futuwwa" was conceptualised by deriving from the word "feta". Futuwwa was used in several meanings such as ignoring the flaws of friends, keeping the rights and interests of others above their interests, welcoming and respecting everybody regardless of Muslims and nonMuslims and showing considerable respect everybody.

\footnotetext{
* Dr. Öğr. Üyesi, Akdeniz Üniversitesi, İlahiyat Fakültesi, Türk-İslam Edebiyatı. Asst, Prof. Dr., Akdeniz University, Faculty of Theology, Turkish-İslamic Literature ORCID 0000-0002-2548-211X mehmetsahin@akdeniz.edu.tr ** Dr. Öğr. Üyesi, Akdeniz Üniversitesi İlahiyat Fakültesi Din Eğitimi Anabilim Dal1. Asst, Prof. Dr., Akdeniz University, Faculty of Theology, Religious Education. ORCID 0000-0003-3322-0723 serefgokus@akdeniz.edu.tr

Cite as/ Atıf: Şahin, M., Göküş, Ş. (2020). Şeyh Ahî Dâ‘̂i Fütüvvetnâmesi’nde ahlâkî değerler. Turkish Studies Religion, 15(2), 237-254. https://dx.doi.org/10.29228/TurkishStudies.43627

Received/Geliş: 15 May/Mayıs 2020

Accepted/Kabul: 20 June/Haziran 2020

Copyright $(C)$ INTAC LTD, Turkey
} 
The works in the form of nizamname, which are about the morality, rule and power of futuwwa, were called fütüvvet-name. Fütüvvet-names are the handbooks of Turkish-Islamic guild which discussed the subject of personal, social and business ethics to create a virtuous society and were applied by the craftsmen and craftsmen unions in Anatolia from 13th century and 19th century. These are books that adopt the principles of chastity, justice, goodwill and wisdom in individual and vocational education and teach values such as truth, generosity, humility, repentance, safety, advice and loyalty. These moral values were taught by the TurkishIslamic guild, an institution of non-formal education. Thus, efforts have been made to ensure social unity and solidarity and to create a common culture. In this sense, Arabic, Persian and Turkish fütüvvet-names were written. These fütüvvet-names and the studies on it have been shown as far as possible. This study aims to examine the moral values in the futuristic version of Sheikh Ahî Dâ'î et-Tarsûsi, who was understood to have lived in the late 14th and early 15th centuries, among the most sizable fütüvvet-names. As a result of the research prepared with the method of document analysis, it was seen that the work of Sheikh Ahî Dâ‘î was close to Old Anatolian Turkish in terms of language characteristics and the moral values in fütüvvet-name were similar to other fütüvvet-names and the common themes overlapped.

There is no information about Ahî Dâ'î in the sources. The limited information is drawn from his single copy. The name of the author, who was understood to have lived in the late 14th and early 15th centuries, is Sheikh Ahî Dâ'î et-Tarsûsî. However, according to Cin and Akçan, it is doubtful that the poet's name is Ahî Dâ‘î. Ahî Dâ‘î is from Tarsus. The fact that he has a lot of information about Naqshbandis, Bektashi, Rifai, Qadiri and Mawlawi in his poetry, and his frequent mention of his activities, shows that he is a sheikh. According to Topak, there is a possibility that Ahî Dâ'î may be the "Sheikh Mencek Baba from Turkestan", who was med fun in the mausoleum in Tekke neighbourhood in Mersin Tarsus. Ahî Dâ‘î, prose fütüvvet-name writer Şeyh Seyyid Hüseyin b. Sheikh Seyyid is the sheikh of Gaybi.

Ahî Dâ‘î Fütüvvet-name is a regulation that the ahîs practised and followed in the lodges they lived in. The principles in this regulation cover the good and bad ethical values that the tradesman should follow, the stages of providing the ethical education of the tradesman and the processes they turn into a behaviour. It is classified as an indispensable principle that has recently entered the profession, mastered in the profession.

Ahî Dâ‘î Fütüvvet-name is a work that includes values such as wisdom, truthfulness, generosity, heroism, sacrifice, alperism, hospitality, patriotism, struggle and helpfulness against a danger together. These values in fütüvvet-name were taught to the public through the Turkish-Islamic guild, so the public education was provided. The basis of these values relies on the religion of Islam. The principles of chastity, charity, wisdom and justice are the basis of Islamic moral values. The factor that creates the values in man is the ego of man. The ego also has powers such as thinking, lust, and anger. Wisdom with the power of thinking, bravery / bravery with anger, and chastity with the power of lust appear. The balance between these powers is achieved by justice. With the balance of these powers, virtue is revealed, and with a little or a large number of residues. For moral education to be healthy, the soul must be taught. For this reason, in Ahî Dâ'î Fütüvvet-name, there is exquisite finishing based on moral education. Basic values such as integrity, repentance, generosity, humility, loyalty, advice to your brother, work to reach the right path, patience, friendship, everyone's right, bravery, courage, and honesty were taught to the public by the guild.

Ahî Dâ'î explained in plain language what the beautiful morals and values followed by the guild were in his work. Humanistic, moral, and spiritual values are handled as a whole and on the religious-mystical ground. It aimed to ensure unity and solidarity of these values in the society, to create a common culture and to moralize the professional groups with the same morality. Individual and social personality was built by teaching moral values through moral education, which is a lifelong, conscious, and targeted education system. Thus, the commonly accepted principles and beliefs and moral values were created by providing common emotion and thought unity in the society using futuwwas.

There are many lyrical and didactic poems in Ahî Dâ‘î Fütüvvet-name that contain faith, morals and values. This work is a work that complies with Islamic principles, is based on respect for people, does not exclude anyone, and aims to educate people spiritually. Quotations from verses and hadiths were frequently made in teaching moral values in the work. In this context, the fact that moral principles are based on religious resources caused the internalization of behaviours more effectively on the public. In personal and professional development, values such as justice, honesty, integrity, patience, respect, love, awareness of responsibility, patriotism, helpfulness, and solidarity were taught to members of the organization. From this point of view,

Turkish Studies - Religion, 15(2) 
fütüvvet-names are the handbook of the Turkish-Islamic Guild, a non-formal education institution where moral virtues and values were taught.

In Ahî Dâ'i Fütvvet-name, there are both the principles of vocational education, moral values and stages of religious education. The principles of belief, morality, knowledge, and art-centred in the fütüvvetname were put into practice by the organization of the Turkish-Islamic Guild. Based on Ahî Dâ'î’s work, It is seen that there is a goal to raise an individual who is developed in all respects with his knowledge, belief, profession, morality and literature.

Keywords: Moral Values, Ahi-Order, Ahî Dâ‘î, Fütüvvetnâme, Non-Formal Education

Öz: Fütüvveti ve fütüvvetin ahlak, kural ve erkânını konu edinen adeta nizamnâme şeklindeki eserlere fütüvvetnâme denilmiştir. 13. yüzyıldan 19. yüzyıla kadar Anadolu'da esnaf ve sanatkâr birlikleri eliyle uygulanan, erdemli bir toplum oluşturmak için kişisel, toplumsal ve iş ahlakını konu edinen fütüvvetnâmeler, ahîlik teşkilatının el kitaplarıdır. Bireysel ve meslekî eğitimde iffet, adalet, şecaat ve hikmet ilkelerini benimseyen, doğruluk, cömertlik, alçak gönüllülük, tevbe, emniyet, nasihat ve vefa gibi değerleri öğreten kitaplardır. Bu ahlâkî değerler, yaygın eğitim merkezi olan ahîlik kurumu eliyle öğretilmiştir. Böylece toplumsal birlik ve beraberliğin sağlanması ve ortak kültürün oluşturulması için gayret gösterilmiştir. $\mathrm{Bu}$ anlamda Arapça, Farsça ve Türkçe fütüvvetnâmeler yazılmıştır. Bu fütüvvetnâmeler ve üzerine yapılan çalışmalar tespit edilebildiği kadarıyla gösterilmiştir. Bu çalışmada amaç, manzum fütüvvetnâmeler arasında en hacimli fütüvvetnâme olan, 14. yüzyılın sonları ile 15. yüzyılın başlarında yaşadığı anlaşılan Şeyh Ahî Dâ'î et-Tarsûsî'nin Fütüvvetnâmesi'ndeki ahlâkî değerleri incelemektir. Doküman incelemesi yöntemiyle hazırlanan araştırma neticesinde, Şeyh Ahî Dâ‘̂̂’nin eserinin dil özellikleri açısından Eski Anadolu Türkçesine yakın olduğu, Fütüvvetnâme'deki ahlâkî değerlerin diğer fütüvvetnâmelerle benzer olduğu ve ortak temaların birebir örtüştüğü görülmüştür. Türk-İslam Edebiyat1, kültür ve medeniyetinin temellerini oluşturan fütüvvetnâmelerden biri olan Ahî Dâ‘î Fütüvvetnâmesi’nde hem meslekî eğitimin ilkeleri hem ahlâkî değerler hem de dinî eğitimin aşamaları vardır. Fütüvvetnâme'deki inanç, ahlak, bilgi ve sanat merkezli ilkeler ahîlik teşkilatı eliyle uygulamaya konulmuştur. Eserinden hareketle Ahî Dâ'î̀nin; ilmiyle, inanciyla, mesleğiyle, ahlakıyla, edebiyle tüm yönlerden gelişmiş bir birey yetiştirilmesi hedefinin olduğu görülmektedir.

Anahtar Kelimeler: Ahlâkî Değerler, Ahilik, Ahî Dâ‘î, Fütüvvetnâme, Yaygın Eğitim.

\section{Giriş}

Fütüvvet; genç, yiğit, cömert, kahraman, genç hizmetçi, delikanlı, kuvvetli (İbn Kayyım ElCevziyye, 2017: II:775) gibi anlamlara gelen Arapça fetâ kelimesinden türetilmiştir. İslam öncesi Arap kabileleri arasında şerefi için mücadele edip kahramanlık gösteren ve cömertlik yapan kimse için fetâ kelimesi kullanılmıştır. (Sarıkaya, 2002: 33) Türkçe'de fetâ kelimesinin karşılığı olarak "ahi, yiğit, alp, er" gibi kelimeler söylenirken, Farsçada ise "fütüvvet-dâr ve civân-merd" kelimeleri tercih edilmiştir. (Pırlanta, 2017: 365; Gölpınarl1, 2011: 17). Fetâ kelimesi Kur'an-1 Kerim'de de farklı türevleriyle beraber geçmiştir. Kur'an'da dört yerde (Enbiyâ, 21/59-60; Kehf, 18/60, 61; Yûsuf, 12/36) genç, bir ayette (Yûsuf, 12/30) köle, bir yerde hizmetçi (Yûsuf, 12/62) anlamında kullanılmıştır. Fetâ’nın çoğul ifadesi olarak iki ayette "fityetü", (Kehf, 18/10, 13) bir ayette "fityânihi", (Yûsuf, 12/62) iki ayette ise "feteyât" (Nûr, 24/33; Nisâ 4/25) şeklinde geçmiştir. Bir yerde ise iki genç (Yûsuf, 12/36) anlamında kullanılmıştır. Özellikle Kehf sûresi 13. ayet ${ }^{1}$ ile Enbiyâ sûresi 60. ayet ${ }^{2}$ fütüvvetin esası kabul edilmiştir. Fütüvvet kelimesi ise fetâ kelimesinden türetilerek kavramlaşmıştır. (Debbağoğlu, 1979: 259). Fütüvvet, dostların kusuruna bakmama, başkalarının haklarını ve çıkarlarını kendi menfaatinden üstün tutma, müslî̀m gayrı müslî̀m gözetmeksizin misafir edip, herkese bolca ihsanda, hürmette bulunma gibi anlamlarda kullanılmıştır. (Uludağ-Ocak, 1996: 259-263). Fütüvvet kavramını ilk kullanan Sülemî (ö.412/1021) olmuştur. Sülemî, fütüvveti,

\footnotetext{
1 "Biz sana onların haberlerini gerçek olarak anlatıyoruz: Şüphesiz onlar Rablerine inanmış birkaç genç yiğitti. Biz de onların hidayetlerini artırmıştık." Kehf, 18/13.

2 “(İçlerinden bazıları), "İbrahim denilen bir gencin onları diline doladığını duyduk" dediler." Enbiyâ 21/60.
} 
Allah'ın emir ve yasaklarına uyma, ibadetleri güzel yapma, kötülüklerden sakınma ve ihsan duygusuyla hareket ederek güzel ahlaka sahip olma şeklinde tarif etmiş ve cömertlik, mürüvvet ve asalet gibi erdemlerle ilişkilendirerek ahlâkî bir boyut kazandırmıştır. (Sülemi, 1977: 22-24). Bu ahlâki nitelikler ise haksızlığa karşı durma, güzel sözlü olma, cana ve mala zarar vermeme, eli açık olma, cömertlik, yardımseverlik, kibirlenmeme, mertlik ve yiğitliktir. (Anadol, 1990: 2-3).

Ahlak ve fikir hareketi olan fütüvvetler ilk defa Müslüman Arap topraklarda doğmuş ve diğer İslam beldelerine yayılmıştır. Arap cahiliye dönemindeki fetâ anlayışının Ahîlik fütüvvetine dönüşmesi çeşitli aşamalardan geçerek şekillenmiştir. Sosyal bir kavram olan fütüvvet 9. yüzy1lda içtimai, iktisadî ve siyasî bir kuruma dönüşmüştür. 12. yüzyılda ise Abbasî devleti döneminde resmî bir fütüvvet teşkilatı haline gelmiştir. Bu tarihten sonra ise tasavvufî fütüvvet anlayışına dönüşerek yaygınlaşmıştır. 13. yüzyıldan itibaren ise bir yandan dergâhlarda sufî bir kurum hüviyeti devam ederken, diğer taraftan ise meslekî bir kurum hüviyetine bürünerek Ahîlik fütüvveti ortaya çımıştır. Abbasî halifesi Nâsır Lidinillah, fütüvvet kurumunu resmileştirirken fikri temellerini oluşturmada mutasavvıf Şehabeddin Sühreverdî'den yardım almıştır. Halifenin emriyle Anadolu'ya gelen Sühreverdî, Anadolu Selçuklu Sultanı I. İzzeddin Keykâvus'la 1214 yılında görüşerek, Anadolu'ya fütüvveti getirmiştir. Türk ahiliğinin kurucusu Ahî Evren değil, Ahî Evren'den önce İran'da yaşamış olan Ahî Türk'tür. Anadolu ahiliği ise Ahî Evran'la birlikte gelişmiş ve tasavvufî bir nitelik kazanmıştır. Özellikle Anadolu fütüvvet ehli için Ahî Evren ayrı bir yere sahiptir ve yetmiş iki buçuk esnafin pîri kabul edilir. (Sarıkaya, 1999: 58). Bu tarihlerden itibaren de Ahî fütüvvetnâmeleri görülmeye başlanılmıştır. (Ocak, 1996: 261-263). Fütüvvetin yeniden yapılandırılmasında mutasavvıflar etkin rol oynamıştır. Fütüvvetten ilk bahseden sûfì Cafer-i Sâdık (el-Cevziyye, 1983: II:354) olmakla birlikte bu konuda ilk eserleri Tirmizî, Cüneyd-i Bağdâdî, Sülemî ve İbn-i Rabî gibi mustasavviflar vermiştir. (Gölpınarlı, 1949-1950: 3-354). Önde gelen sufilerin bu konuda eser vermesi ile birlikte fütüvvet edebiyatı doğarak birçok özgün eser ortaya çıkmıştır. Türk edebiyatı da fütüvvetnâmeler konusunda oldukça zengindir.

\section{Fütüvvetnâmeler}

Fütüvveti ve fütüvvetin ahlak, kural ve erkânını konu edinen adeta nizamnâme şeklindeki eserlere fütüvvetnâme denilmiştir. Fütüvvetnâmeler, fütüvvet teşkilatının işleyiş biçimini ve mensup olanların davranışlarını düzenleyen el kitabı gibidir. Aynı zamanda 13.-16. yüzyıllarda Anadolu sahasının dinî, kültürel ve toplumsal yaşantısını bize aktarması açısından da son derece önemli ve ilk el kaynaklardır. (Köprülü, 1947: 445-446). Fütüvvet hareketi aynı zamanda nispet edilen kişi açısından da ikiye ayrılmıştır. Hz. Ali'ye nispet edilen kola seyfî, Hz. Ebu Bekir'e nispet edilen kola ise kavlî adı verilmiştir. Seyfîler daha çok askerî birliklerin bağlı olduğu kolken, kavlîler ise meslek ve zanaat sahibi kişilerin bağlı olduğu koldur. (Sarıkaya, 1999: 56). 9.-13. yüzyılları kapsayan sûfî fütüvvetnâmeleri, 13.-14. yüzyılları kapsayan Fütüvvet Teşkilatına ait fütüvvetnâmeler ve 13.-16. yüzyılları kapsayan Ahî Loncalarına ait fütüvvetnâmeler olmak üzere üç fütüvvetnâme türü bulunmaktadır. (Ocak, 1996: 264-265). Fütüvvetnâmelerde ana muhteva tevhid, adab, Allah rızasını kazanmak, işini düzgün yapmak, her kötülüğü terketmek ve güzel ahlaklı olmaktır. Bu sebeple birçok fütüvvetnâmede konular, ifadeler, semboller, mazmunlar ve fütüvvet ağacı gibi motifler ortaktır ve genellikle müellifleri belli olmayan anonim eserlerdir. (Cumhur, 1978: 85). İlk fütüvvetnâmeler hem Arapça ve Farsça hem de Türkçe olarak kaleme alınmıştır. Ancak ilk yazılan fütüvvetnâmeler Arapçadır.

\subsection{Arapça Fütüvvetnâmeler}

Horasanlı müfessir, muhaddis ve sûfî olan Muhammed b. Hüseyin Sülemî'nin Kitâbu'lFutuvvaisimli eseri bilinen en eski fütüvvetnâmedir. (Ateş 1977; Ayasofya, 2049). Sülemî’ den sonra fütüvvet konusuna değinen kişi ise Abdülkerim b. Hevâzin Kuşeyrî'dir. Kuşeyrî, er-Risâle isimli eserinde fütüvvet babını açarak, fütüvvetle ilgili bilgi vermiştir. Abdullah Ensârî el-Herevî’nin Kitabu' '-Fütüvvet' $\mathrm{i}$ bu alanda yazılmış ikinci eserdir. (Küçük, 2000: 137-166). Üçüncü müstakil eser 
ise Ali b. Hasan b. Ca'dveyh'in Kitâbu Mir'âti'l-Mülki'l-Mürüvvet isimli eseridir. Bu eser Selçuklu Devletinin veziri Nizâmülmülk’e ithaf edilmiştir. (Millet Kütüphanesi, Nr. 479). Ali b. İlyas enNakkâş el-Harpûtî'nin Tuhfetü'l-Vesâyầ sıdır. Harpûtî eserini Halife Nâsır'ın oğlu Ebu Hasan Ali'ye ithaf etmiştir. Bu eser Anadolu'da yazılan en eski fütüvvetnâmelerden biridir ve Türkçe fütüvvetnâmelere kaynaklık etmiştir. Özellikle Burgazî, bu eserden sıklıkla iktibaslar yapmıştır. (Gölpınarlı 1949-1950: 209; Anadol, 1991: 122). Ebu Hasan Ali b. Nâsır Lidinillah'1n Umdetü'lVesîle isimli eseridir. Bu eser günümüze ulaşmamıștır. (Gölpınarlı, 1949-1950: 13). Abdurrezzak Kâşânî'nin Tuhfetu'l-İhvân Fî Hasâisi'l-Fityân isimli eseridir. Bu eseri Şehabeddin Sühreverdî'nin torunu Ali b. Yahya'nın talebi üzerine yazmıştır. Kâşânî, bu eserini daha sonra Farsça'ya da çevirmiştir. (Uludağ, 2002: 5-6; Ergül, 2013: 114). Bunların dışında müellifi belli olmayan, anonim fütüvvetnâmeler de bulunmaktadır. Süleymaniye Kütüphanesi, Ayasofya 2049 numaralı Mecmua'da fütüvvetle ilgili 22 risale yer almaktadır.

\subsection{Farsça Fütüvvetnâmeler}

Şehabeddin Sühreverdî’nin Fütüvvetnâme'si bu alanda yazılmış en önemli Farsça eserlerden biridir. Abbasi halifesi Nasır, Şehabeddin Sühreverdî’ye fütüvvet teşkilatının usul ve erkânını belirlemek için yazdırmıştır. Fütüvvetnâme olarak bilinen eserin adı Risâletü'l-Fütüvve' dir. (Çatak, 2012: 45; Ayasofya, 2049). En meşhur Farsça fütüvvetnâmelerden biri de Şair Nâsırî tarafindan kaleme alınmış olan Fütüvvetnâme'dir. Emir Ahî Muhammed'e ithaf edilmiştir. (Ayasofya, 2049; Gölpınarl1, 1949-1950: 279-285). Ayrıca Necm-i Zerkûb olarak bilinen ancak asıl adı Necmüddin Ebu Bekir Muhammed b. Mevdûd et-Tebrîzî'nin Fütüvvetnâme'si de vardır. (Ayasofya, 2049, vr.170b-174a; Gölpınarl1, 1949-1950: 211). Rükniye tarikatının kurusucu olan İranlı şair ve âlim Alaüddevle-i Simnânî'ye nispet edilen Risâletün fi'l-fütüvve de bir başka önemli eserdir. (Veliyyüddin Efendi, nr. 1796; Orhan 2016: 124). Hâtifî ve Ferîdüddin Attar'a ait olarak gösterilen ancak her ikisine de aidiyeti şüpheli olan Fütüvvetnâme de bulunmaktadır. (Ceylan, 2016: 173-181). İranlı mutasavvıf, müfessir ve şair Hüseyin Vâiz-i Kâşifî’nin Fütüvvet-nâme-i Sultânî isimli eseri vardır. (Karaismailoğlu, 1999: 16-18; Gölpınarlı, 1995: 127-155). Ayrıca müellifi bilinmeyen Farsça fütüvvetnâmeler de mevcuttur. (Gölpınarl1, 1949-1950: 24-29; Torun, 1998: 48; Asfhari, 2003).

\subsection{Türkçe Fütüvvetnâmeler}

Edebî bir tür olan fütüvvetnâmeler ahlâkî eserlerin bir koludur. (Levend, 1963: 96-97). Fütüvvetin temeli özellikle tasavvufa dayandığ için ortak ana tema din, tasavvuf ve ahlaktır. (Ocak 1996: 264-265). Ortak temanın kullanıldığ fütüvvetnâmeler dönemin din ve ahlak anlayışını, sosyal ve kültürel yapıyı, ekonomik hayatı, dönemin dil, edebiyat ve söz varlığı alanında günümüze kaynaklık eden eserlerdir. Türkçe yazılan fütüvvetnâmelerde merasimlerin adab ve erkanı da yer aldığı için toplumun ortak duygu ve düşüncede birleşmesini de sağlamış eserlerdir. Türk Edebiyatında fütüvvetnâmeler hem manzum hem de mensur olarak kaleme alınmıştır.

\subsubsection{Manzum Fütüvvetnâmeler}

Manzum fütüvvetnâmelerde fütüvvetle ilgili meslekî ve iktisadî hususlara değinilmemiş, tasavvufî ahlak konularına yer verilmiştir. Kendilerine dinî ve tasavvufî eserleri kaynak edinmişlerdir. (Yeniterzi, 2001: 321-323). Şeyh Eşref b. Ahmed'in Fütüvvetnâme'si, Anadolu'da bilinen ilk Türkçe manzum fütüvvetnâmedir. Dinî, tasavvufî ve ahlakî konuların ağırlıklı olduğu 444 beyitten oluşan eser 1452 yllında Edirne'de istinsah edilmiştir. (Bilgin, 1992: Güneş, 2016). İkinci eser ise müellifi bilinmeyen tek yazma nüshası Süleymaniye Kütüphanesi'nde bulunan Fütûhnâme'dir. (Altuner, 1999: 23-38). Bu eser, tasavvufî ahlakı konu edinen bir mesnevîdir. Manzum fütüvvetnâme örneklerinden bir diğeri ise Esrâr Dede'nin Fütüvvetnâme'sidir. 1796 y1lında “fe'ilâtün/mefâ'ilün/fe'ilün vezniyle yazılmış ve 176 beyitten müteşekkil bir mesnevîdir. (Yeniterzi, 2001: 321-323; Torun, 1998: 57; Cin-Akçan, 2018: 104). Bunun yanında Ahî Dâ‘'î? fütüvvetnâmesi vardır ki aşağıda tanıtacağız. 


\subsubsection{Mensur Fütüvvetnâmeler}

Anadolu sahasında Türkçe olarak kaleme alınmış bilinen en eski mensur fütüvvetnâme, Yahya b. Halil. b. Çoban el-Burgazî'nin Fütüvvetnâmesi'dir. 1507 yılında istinsah edilen bu eser, Çobanoğlu Fütüvvetnâmesi olarak bilinir. (Gölpınarlı, 1953-1954: 76-153; Ali Emiri, nu. 135; Yılmaz, 2006: 13-14; Cin-Akçan, 2018: 103). Burgazî, İsmail Gökçe tarafından hazırlanan yüksek lisans tezinde hatalı olarak Birgivî olarak geçmektedir. (Gökçe, 2019: 4). Eserde yiğitlik, ahîlik ve şeyhlik ön plana çıkarılarak 740 edeb ve erkanın 124'ü anlatılır. Şeyh Seyyid Hüseyin b. Şeyh Seyyid Gaybî'nin Fütüvvetnâme'si ise ikinci Türkçe fütüvvetnâmedir. Bu fütüvvetnâme de Gölpınarlı tarafından neşredilmiştir. Yüz yirmi dört edeb ve erkanın anlatıldığı erkan ağırlıklı bir fütüvvetnâme olan eserde, Fatih Sultan Mehmet'e medhiye bulunmaktadır. Bu sebeple de Fatih döneminde yazıldığı düşünülmektedir. Müellifi hakkında çok fazla bilgi bulunmamaktadır. (Gölpınarlı, 19551956: 25-155; Cin-Akçan, 2018: 103). Anadolu sahasında yazılmış en kıymetli eserlerden biri de Seyyid Muhammed b. Seyyid Alaeddin el-Hüseynî er-Radavî'nin Miftâhu'd-Dekâik Fî Beyâni'lFütüvve ve'l-Hakâik isimli eseridir. 17. yüzyılda yaşamış olan Razavî'nin bu eseri Fütüvvetnâme-i Kebîr veya Miftâh-1 Dekâyık olarak bilinir. (Gülten-Yılmaz, 2014; Yazmalar, no:8602/1). Bu eser Rahşan Gürel tarafindan doktora tezi, Numan Meriç tarafından ise yüksek lisans tezi olarak çalışılmıştır. (Gürel, 1992; Meriç, 2013). XVI. yüzyılın son dönemleri ve XVII. yüzyılın ilk başlarında yaşayan Bursevî Hâce-i Cân Ali'nin kaleme aldığı Fütüvvetnâme'si vardır. TDK Kütüphanesinde A/332 numaralı mecmuada Bahru'n-Nihâye olarak kayıtlıdır. Müellif kendisini Hz. Abbas'ın soyuna nispetle Nesl-i Abbas olarak kabul etmektedir. Bu sebeple de fütüvvet kollarını Hz. Abbas'a nispet etmektedir. (Meriç, 2013: 16-17; Torsun, 1998: 54-55). Diğer bir fütüvvetnâme ise Fütüvvetnâme-i Ca'fer Sâdı $k^{\prime}$ tır. Bu fütüvvetnâmenin müellifi ve müstensihi hakkında bilgi bulunmamaktadır. Şiiliğin 12 imamından biri olan Ca'fer-i Sadık'ın soyu baba tarafından Hz. Ali'ye ulaştığg için Hz. Ali'ye daha fazla yer verilmiştir. Fütüvvetnâmede Alevî-Bektâşî-Şiî inançları hakimdir. (Sarıkaya, 2008: 5-12). Sadece hamam, berber ve sünnetçi gibi esnafa yönelik olarak yazılan ve müellifi bilinmeyen Selmân-1 Pâk Fütüvvetnâme'si (İsmail Saib I, nu: 2883) vardır. 35 varaktan oluşan bu eser Ali Torun tarafindan yayımlanmıştır. Eserin müellifi Selmân-1 Fârisî değildir. Selmân-1 Fârisi, dellak, nâtır, külhan, berber ve sünnetçi gibi esnafın piri kabul edildiği için bu isimle anılmıştır. (Torun, 1998: 127, 128, 150-152). Kütüphanelerimizde müellifi belli olmayan ancak içerikleri birbirine benzeyen yüzlerce fütüvvetnâme bulunmaktadır. Kitâbı-1 Hiref, Kitâb-1 Sakka, Sakkaname, Tiraşname, Risâle-i Hayyatân, Risâle-i Habbâzan gibi fütüvvet ehlinin oluşturduğu meslek gruplarını anlatan eserler de fütüvvetnâme olarak kabul edilmektedir. (Torun, 1998: 42-58). Kütüphanelerde tercüme veya özet olarak yazılmış fütüvvetnâmeler de bulunmaktadır. Bunlar ise Derviş Mim Ahmed Fütüvvetnâmesi ${ }^{3}$, Yâsin-i Rufâ'i Fütüvvetnâmesi ${ }^{4}$, Şeyh Abulkadir Fütüvvetnâmesi ${ }^{5}$, Şeyh Mûsâ Fütüvvetnâmesi ${ }^{6}$, Şeyh Ahmed Fütüvvetnâmesidir. ${ }^{7}$ (Torun, 1998: 5557; Cin-Akçan, 2018: 104).

\section{Ahî Dâ‘î ve Fütüvvetnâmesi}

Ahî Dâ‘î hakkında kaynaklarda bilgi bulunmamaktadır. Kısıtlı sayıdaki bilgi ise tek nüsha olan eserinden çıkarılmaktadır. 14. yüzyılın sonları ile 15. yüzyılın başlarında yaşadığı anlaşılan müellifin adı, Şeyh Ahî Dâ'î et-Tarsûsî'dir. Ancak Cin ve Akçan'a göre ise şairin isminin Ahî Dâ‘̂̂ olması şüphelidir. (Cin-Akçan, 2018: 104). Ahî Dâ‘̂̂, Tarsus'ludur. Manzumelerinde Nakşbendî, Bektâşî, Rifâî, Kadirî ve Mevlevîlikle ilgili çok fazla bilgi olması, irşad faaliyetlerinden sıkça bahsetmesi onun şeyh olduğunu göstermektedir. Topak'a göre ise Ahî Dâ‘̂̂’nin Mersin Tarsus'ta bulunan Tekke mahallesindeki türbede medfun olan "Türkistanlı Şeyh Mencek Baba" olma ihtimali

\footnotetext{
${ }^{3}$ Milli Kütüphane, Yazmalar, B.346/33, vr.238a-247a.

${ }^{4}$ Süleymaniye Kütüphanesi Hacı Mahmut Kitapları, nu. 2532.

${ }^{5}$ Çorum İl Halk Kütüphanesi, nu.885.

${ }^{6}$ Süleymaniye Kütüphanesi Pertevpaşa Bölümü nu.613, vr.175b-207b.

${ }^{7}$ Milli Kütüphane, Yazmalar, A5594, vr. 92b-94b.
} 
vardır. (Topak, 2016: 35). Ahî Dâ‘î, mensur fütüvvetnâme yazarı Şeyh Seyyid Hüseyin b. Şeyh Seyyid Gaybî'nin şeyhidir. (Topak, 2016: 35).

Ahî Dâ‘̂̂’nin manzum olarak kaleme aldığı fütüvvetnâmesinin tek nüshası bulunmaktadır. ${ }^{8}$ 87 varaktan oluşan fütüvvetnâme H.880/M.1475-6 tarihinde "fâ'ilâtün/fâ'ilâtün/fâ'ilün" vezniyle yazılmıştır. (Cin-Akçan, 2018: 104).

Çün sekiz yüz seksen oldı hicrete

Geçdi sekiz ay dahı andan öte (vr.15)

Fütüvvetnâme, dil özellikleri açısından Eski Anadolu Türkçesine yakındır. En önemli özelliği ise manzum fütüvvetnâmeler arasında en hacimli fütüvvetnâme olmasıdır. Muhteva olarak diğer manzum fütüvvetnâmelerle benzerlik göstermektedir. (Cin-Akçan, 2018: 111; Köksal, 2019) Ahlâkî değerlerin tespitinde kullanılan şiirlerde, Kübra Akçan tarafindan hazırlanan çalışma esas alınmıştır. (Akçan, 2018)

\section{Ahlâkî Değerler}

Tarih boyunca ideal bir insan ve toplum meydana getirmek, bir arada yaşamak için ahlaki değerler oluşturulmuştur. Toplumun düzen içinde devam etmesi için insani değerlere ve bunların sonraki nesillere öğretilmesine büyük önem verilmiştir. Her bireyin başına düzeni sağlamak için polis konulamayacağına göre, insanların gönüllü olarak kabul edeceği ortak değerler eğitim yoluyla topluma öğretilmiştir. Toplumsal süreklilik ve insanlar arası ilișkiler ancak bireylerin ortak değerlere bağlılığı oranında düzenli yürüyebilir. Bu açıdan değer, "Bir ulusun sahip olduğu sosyal, kültürel, ekonomik ve bilimsel değerlerini kapsayan maddi ve manevi ögelerin bütünü'” olarak tarif edilmektedir. Değerler insanı geliştirir, iyi yanlarını ortaya çıkarır. Değerler aynı zamanda bir şeyin aynı türden olanlara kıyasla konumunu da belirler. İnançlar kişinin değerlerini oluştururlar. $\mathrm{Bu}$ durumda da değerler kişinin davranışlarına etki ederler ve davranışları yargılamayı sağlayan anlayışlar geliştirirler. $\mathrm{O}$ halde insanı insan yapan temel faktör değerlerdir. Bir bakıma değerler kişinin davranışlarının nedeni ve karakterinin bir parçasıdır. (Oğuzhan, 1991: 45; Tepe, 2002: 346 Ekşi-Katılmış, 2011: 9; Güngör, 1993: 21; Aydın-Güler, 2012: 3; Yörükoğlu, 1998: 167).

Değer, bireyin bir olay karşısındaki tutum ve davranışlarıdır. Aynı zamanda doğru ve yanlışın ne olduğunu söyleyen ve ahlâkî olgunlaşmayı açıklayan kavramdır. Değerler eğitimi, hayat boyu devam eden değer kazanma ve kazandırma süreçleridir. (Yaman, 2016: 158). Değerler eğitimindeki ana hedef, doğuştan getirilen yetenekleri geliştirmek, bireyin kişiliğini oluşturmak, bireyin mükemmelleşmesine yardımcı olmak ve onu kötülüklerden koruyacak ahlaki erdemlerle donatmaktır. Böylece bireyin hayatını daha anlamlı kılar, bireyin ruhsal dengesini korur, kişiliğini güçlendirir ve karakterini sağlamlaştırır. (Aydın-Güler, 2012: 17). Değerler eğitimi; "Değerlerin açık ve bilinçli şekilde öğretilmesi süreci olup doğrudan ya da dolaylı olarak kişilerin değerler hakkındaki anlayış ve bilgisini geliştirerek onların bireysel ve mensubu olduğu topluma uyumlu bir şekilde davranabilmeleri için gerekli olan bilgi ve becerilerin içselleştirilmesi faaliyeti olarak tanımlanmaktadır." (Keskin, 2016: 74-77). İşte fütüvvet teşkilatları bu değerleri ömür boyu sürdürmeyi ilke edinmiş kurumlardır. Fütüvvet ilkeleri ideal insan yetiştirme üzerine kuruludur. İdeal insanda olması gereken en temel özellik ise ahlaktır. Fütüvvetin ideal insan tipi ahilik teşkilatı ile vücut bulmuştur. Ahilik teşkilatındaki en önemli ahlâkî kurallar ise ahlak temizliği, adalet ve yiğitliktir. Ahlâkî ilkeleri ise doğruluk, cömertlik, bilgelik, namusluluk, hakkı gözetme, hizmet ve denge gibi değerlerden oluşmaktadır. Bu değerlere sahip insanlardan kurulu bir toplum olușturma, birlik ve beraberliği sağlama fütüvvetin ana hedefleridir. Anadolu'da Ahîlik, fütüvvet anlayışının tasavvufla yoğrulmuş halidir. Ahiliğin doğru anlaşılabilmesi için, fütüvvetin ahlâkî temellerinin

\footnotetext{
${ }^{8}$ Marmara Üniversitesi Kütüphanesi Nadir Eserler Koleksiyonu, nu.12881/Y004.

9 TDK, Güncel Türkçe Sözlük, https://sozluk.gov.tr/ (Erişim tarihi: 14.05.2020).
} 
bilinmesi zaruridir. Bu sebeple Ahî Dâî’nin fütüvvetindeki ahlâkî değer ve erdemlerin tespitine çalışacağız.

Ahî Dâ‘̂̂’nin fütüvvetnâmesi, Ahîlerin bulundukları zaviyelerde uyguladıkları ve uydukları bir nizamname niteliğindedir. Bu nizamnamedeki ilkeler, esnafin uyması gereken iyi ve kötü ahlâkî değerleri, esnafın ahlâkî eğitiminin sağlanma aşamalarını ve öğrettikleri ilkelerin davranışa dönüşmesi süreçlerini kapsar. Mesleğe yeni giren, meslekte ustalaşan ve vazgeçilmez ilkeler olarak sınıflandırılır. Fütüvvet teşkilatlarında mesleğe yeni başlayanların sahip olması gereken değerler şunlardır:

1- Zâhiri ve bâtınını temizlemek, 2- Allah'ın emir ve yasakları ile Hz. Muhammed'in sünnetine tabi olmak, 3- Mü'minlerin hayrını istemek, 4- Eline, beline, diline sahip olmak, 5- Nefsi ölü, gönlü diri olmak 6- Dili açık, gözü bağlı olmak, 7- Dili daima Allah'1 zikretmek, 8- Allah'1 gönlüne yerleştirmek, 9- Nefsi, "Ölmeden önce ölme" mertebesinde olmak, 10- Üstadına isyankâr olmamak, 11- Hak söze inancı olmak, 12- Hak ve adalet üzere olmak, 13- Daima nefsine kahretmek, 14- Büyüklere hizmet etmek, 15- Küçüklere şefkat etmek, 16- Dostlara tevâzû etmek, 17Düşmanlara tahammül etmek, 18- Dervişlere karşı cömert olmak, 19- Dostluğu ve düşmanlığı Allah için etmek, 20- İlim ehline hürmet etmek, 21- Musahiplerine nasihat etmek, 22- Cahiller ile tartışmamak. (Sarıkaya, 2007: 4-5).

Meslekte ustalaşan bir ahîde olması gereken ahlâkî ilkeler ise şunlardır:

1.Cömert olmak, 2.Namazını vaktinde kılmak, 3.Haya sahibi olmak, 4.Terk-i dünya etmek, 5.Helal kazanmak, 6.İlim sahibi olmak, 7.Beyler kapısına varmamak. (Sarıkaya, 2007: 7).

Fütüvvetnâmelerdeki ortak olan ve her ahînin uyması gereken ahlâkî değerler vardır. Bunlar;

1- Cimrilik kapısını kapatıp cömertlik kapısını açmak, 2- Kahır kapısını bağlayıp kanaat ve rıza kapısını açmak, 3- Hırs ve heva kapısını bağlayıp lütf kapısını açmak, 4- Tokluk ve lezzet kapısını bağlayıp açlık ve riyazet kapısını açmak, 5- Halktan eminlik kapısını bağlayıp Hak’tan yana tevekkül kapısını açmak, 6- Herze ve hurâfe söyleme kapısını kapatıp zikr ve tilâvet kapısını açmak, 7- Şeytan fiilleri kapısını kapatıp Allah'a ait fiiller kapısını açmak. (Sarıkaya, 2007: 8).

Fütüvvetnâmelerdeki bu ortak ahlâkî değerlerin Ahî Dâ‘î’nin fütüvvetnâmesinde de aynen olduğunu görüyoruz.

23v8 Yedi baġlaya vü hem aça yedi

Açduġıñ gele yedi ḳaça yedi

23v9 Bağla ef ‘ āl-i zemìmeden yedi

Gelsün ef ‘ āl-i hamīideden yedi

23v10 Buhlı evvel bag̉la raḥmet șaçıla

Bu seḩ̄ ḳapusı aña açıla

23v11 Bag̉la ikincide ḳahrını anı̃

Açıla luțfi ḳapusı tañrınıñ

23v12 Bag̉laya cürmi hevāsından gecçe

Hem ḳanā 'at hem riżāsından gèçe

23v13 Ṭoḳlıḳ u nefsānīden hep gèçile

Bag̉la kim açlıḳ riyāżet açıla 
23v14 Baġlayup hem cümle halḳdan

Holḳı ḳoyup haḳk ḳapusın açasın

23v15 Bag̉la mā-lā-ya 'nì yẻ fâhịiş sözi

Ma' rifet açıla hem ma' nā gözi

24r1 Fi 1-i şeyțānī ne kim var bağlaya

Ol la'īniñ cānın oda țag̉laya

24r2 Fic 1-i Raḥmānīden açasın ḳapu

Her ki seni göre eyleye țapu

24r3 Ehl-i şeddsin zāāir oldıñ sen dahı

$\mathrm{Bu}$ yedi şarț ile bag̉lasa aḩi

\subsection{Doğruluk}

Fütüvvetteki en önemli değerlerden biri niyette, sözde ve fiilde doğruluktur. Fütüvvetteki doğruluk ideal insan tipinin en önemli özelliği kabul edilir. Doğru kişide dürüstlük, sözünün eri olma, sadakat, riyakâr olmama gibi erdemler olur. Bu erdemlere sahip olmayan kişi doğru olamaz ve fütüvveti kirletmiş olur. Doğruluk hikmetin ilk temeli ve ilk dayanağıdır. Doğruluk insanı diğer canlılardan ayıran bir özelliktir. Bir kişi malına ve canına zarar gelecekse bile doğruluktan ayrılmamalıdır. Özellikle dinle ilgili konularda asla yalan söylememelidir. Zira bu Allah'a iftira sayılır. Fütüvvet sahibinin içi ve dışı bir olmalı, açıklayınca utanacağı bir işi yapmamalıdır. Eğer bir kişi doğruluğu ilke edinirse, ona bütün hayır kapıları açılır ve şer kapıları kapanır. Fütüvvet fehli "Öyle ise emrolunduğun gibi dosdoğru ol. Beraberindeki tövbe edenler de dosdoğru olsunlar. Hak ve adalet ölçülerini aşmayın. Şüphesiz O yaptıklarınızı hakkıyla görür." (Hûd 11/112) ayetini ilke edinmelidir. (Kâşânî, 1949-1950: 277-279).

Ahî Dâ'î’ye göre doğru söz insana acı gelir. Ancak fütüvvet ehli acı da olsa doğruyu her daim söylemelidir. Ahîlik kuşağı aynı zamanda doğruluk kuşağıdır. Eğer bir kişi bu kuşağı kuşanırsa, hak ile batılı ayırıp doğru yoldan sapmamalıdır. Temiz olanlar doğru yoldan sapmaz ancak pis olanlar doğru yoldan ayrılır. Gerektiği durumlarda da kişi, doğru tanıklık yapmalıdır. Doğru kişilerde kayg1 olmazken eğri kimselerde ise kaygı çok olur.

9v12 Gerçi țog̉rı söz acı gelür veli

Yegrek oldır söyleye pes hạḳ yolı

35v9 Sen daḩı ḳuşandıñ ise ey aḩi

Toğru var hạkḳıñ yolına sen dahıı

35v10 Bu ḳuşaḳdan ma' nā budur ey 'azīz

Hakḳ u bāṭl ne ise eyle temīz

62v1 Yā ilāhī țog̉ru sözden ayırmag̉ıl

Ṭogrulardan sen bizi ayırmaġı

68v10 Bizi pāk eyle vü pāk ile ḳopar

Ṭogru yoldan bilürem nā-pāk șapar

45v1 Ṭog̉r țanıklıḳ verene ḳaygu yoḳ

Egri olan kişilerde ḳayg̉u çoḳ

www.turkishstudies.net/religion 
Ahî Dâ'î̀’ye göre fütüvvet ehli ticarette alırken de satarken de doğruluktan ayrılmamalıdır. Doğruluktan ayrılmamak için Allah'a dua etmelidir.

62r10 Alur iken yalanı çoḳ söyleme

Șatar iken de ayñen medh eyleme

62r11 Ḥaddi ile olsa işiñ dādı var

Ṭogrulıḳ ile işiñ bünyādı var

62r12 Ṭog̀ru yoldan iledivèrsen saña

Azmayup ḳayıḳmayavuz dört yaña

62r13 Kulagiuz sen ol bize yār-1 Hudā

Dünyā sevmekten bizi sen ḳıl cüdā

Doğru yol için rehber evliyadır. Evliyalar Allah'ın doğru kullarıdır. Onlara tabi olanlar kısa yoldan hidayete ulaşırlar. Kişi doğrular meclisine katılmalı, yalan meclislerinden uzak durmalıdır.

79v1 Evliyādır bildüren tọgru yolı

Evliyādır tañrınıñ țogru ḳulı

44v2 Șuçı șoran kişiler ḥayf ètmeye

Ṭoğrı yolı ḳoyup egri gitmeye

44v3 'A Ādil ola șuçı țog̉rı șora ol

Ḥayf ètmeye vü ḥāli göre ol

51r10 Ger żarūret olur ise varalar

Ṭog̀r1 söyleyüp nașīhat vereler

55r5 Yā ilāhī tọg̀nı eyle yolımız

Ḥāliyā bildürivėrgil ḥālimiz

24v11 Yalan olan ümmetimden olmaya

Ṭogrular meclīsine ol gelmeye

\subsection{Cömertlik}

Cömert olma durumu, eli açıklık, sahâvet, semâhat, verimlilik gibi anlamlara gelmektedir. (Ayverdi, 2010: 202). Fütüvvet ehline göre cömertlik, verilmesi gereken şeyi vermek, verilen kişiyi minnete düşürmeden, bir maksat gütmeden ve karşıllı beklemeden vermektir. Cömert kişi iffetin ve zahitliğin en yüce makamlarına ulaşır. Fütüvvet ehli cömertlikle ilgili "Eğer bilirseniz, (borcu) sadaka olarak bağışlamanız, sizin için daha hayırlıdır" (Bakara, 2/280) ayeti ile "Allah katında cahil bir cömert, cimri âlimden daha sevimlidir." ${ }^{10}$ hadisini ilke edinirler. Nitekim Hz. Peygamber, "Cimri ile cömerdin durumu, gögüsleri ile köprücük kemikleri arasına zırh giyinmiş iki kişinin durumuna benzer. Cömert, sadaka verdikçe, üzerindeki zırh genişler, uzar, ayak parmaklarını örter ve ayak izlerini siler. Cimri ise, bir şey vermek istediğinde zırhın halkaları birbirine iyice geçer, onu sıkıştırır; genişletmek için ne kadar çalışsa da başaramaz." ${ }^{11}$ buyurmuştur. Cömertler insanların ahlaken en üstünüdür ve cömert kişi fütüvvet ehlidir. Cömertlerin yeri cennettir. Cömert kişi kerem ve ihsan sahibidir. Malını verdikçe, harcadıkça sevinir. Cömertlik insanın diğer ayıplarını da örter. Fütüvvet

\footnotetext{
10 Tirmizî, Birr, nu. 40.

${ }^{11}$ Buhârî, Cihâd, nu.89.
} 
ehline göre cömertlerin piri Hâtim-i Tâi'dir. Fütüvvet ehli cömertlikte Hâtim'i örnek almalı, cömertliği en büyük huy edinmelidir. (Kâşânî, 1949-1950: 271-274).

Ahî Dâ‘̂̂’ye göre Allah cömerttir, insan da Allah'ın cömertlik sıfatıyla sıfatlanmalıdır. Cömert kişi cömertlikte Hâtim-i Tâi gibi olmalıdır. Bir kişi o kadar çok vermeli ki gören onu Hâtim zannetmelidir.
42v9 Bir adı dahı cömerddir ey aḩi
Ol adıyla hem-ṣıfat ol sen dahıı
34r13 Birisi baña cömerdlıḳ göstürür
Birisine kendüniñ ḩayrın vèrür
9v3 Ḥātem-i țaydır zamānında bugün
Ehl-i țarsūs hep amānında bugün
9v4 Hem sahāvet hem şecāe atdır işi
Yehm èder hem heybetin gören kişi
9v5 Heybetin gören kişi rüstem șanur
$\mathrm{Ni}^{`}$ metin gören kişi ḥātem șanur

\subsection{Yiğitlik}

Yiğitlik, ahîlik teşkilatındaki en önemli ilkelerden biridir. Yiğitlik, cesur olmak, korkmamak, korkaklıkla saldırganlık arasında dengeli olmaktır. Fütüvvet ehli, kendinden emin olmalı, kendisine emanet edilenleri korumalı, halkın sırlarını saklamalıdır. Tevazu sahibi olmalı, zayıflara merhametle yaklaşmalı, haksızlık karşısında hakkını aramalıdır. Kibirlenmeyen, güvenilir olan ve etrafının ondan emin olduğu kişi yiğit kişidir. (Gölpınarlı, 1949-1950: 214, 313).

Ahî Dâ‘î'ye göre yiğitlerin şahı Hz. Ali'dir. Fütüvvet ehli kendine Hz. Ali’yi örnek almalı, onu rehber edinmeli ve onun gibi yiğit olmalıdır. Fütüvvet kavramının temeli fetâ'ya dayanmaktadır. Fütüvvete mensup olan kişiler yiğitlikte, tevazu ve eminlikte Hz. Ali gibi olmalı, onun yolundan gitmelidir.
74v1 Sen de hem fetā olasin hem yigit
$\mathrm{Bu}$ sözimden alur iseñ sen ögit
9r8 Hem dèdi ol enbiyālar serveri
Bir gazāda lā feta illā ' $A \bar{l}^{-12}$
31r11 Yol eriniñ mürşidi haydar durur
Cümle sāliklere ol rehber durur
31 r12 Țālib iseñ gel berü ey yol eri
Sen daḩı rehber èdin ol Ḥaydarı

\footnotetext{
12 “Ali’den başka yiğit yoktur.” Bu söz, Ali'den başka yiğit, onun kılıcından üstün kılıç yoktur, anlamına gelen "lâ fetâ illâ Alî lâ seyfe illâ Zülfikar"'dan iktibastır. Bu sözü Hz. Muhammed, Hz. Ali için Bedir gazvesinde söylemiştir. İbn Asakir, Tarihu Dımaşk, Darü'l-Fikr, Beyrut, 1995, XLII, s. 71.
} 
31r13 Ḥaḳk Te 'ālā çün aña Ḥaydar dẻdi

Hem Resūlu'llāh dahı̆ rehber dèdi

31r14 Sen dahı rehber țut anı ey aȟi

Haḳk yolı țog̀ru varasın sen dahı

31r15 Haydarī ol haydarī ol haydarī

Ḥaydarī olan bulur peygamberi

54v12 Ol 'alīdür hem fetā vü hem aḩi

Mürşid-i ekmel durur hem şeyh daḩı

54v13 Kim ‘ alì yolın vara oldur fetā

Ḥaḳk yolına ol fetā ola țuta

Ahî Dâ‘î fütüvvetnâmesinde fetâyı peygamberlerin yolu olarak görür ve Kur'an'da geçen genç peygamberlerden örnekler verir. Özellikle Hz. İbrahim, Hz. Yusuf, Hz. Yuşa ve Ashâb-1 Kehf örnekleri verilerek fetâ ahlâkî değeri anlatılır. Hz. İbrahim putları kırarken, Ashâb-1 Kehf batıla karşı dururken yiğitlik göstermiştir.
74r12 Birisidir anıñ İbrāhīm Hูalīl
Aña dahı hem fetā dèdi Celīl
74v3 Birisi Yūsufdur anıñ ey ata
Anıñ adına oḳudı Ḥaḳk fetā
74v4 Kimseye meyl ètmedi ol pāk idi
Ḥaḳk yolında zehresi hem çāk idi
74v9 Hem fetādur Yūşac ibn-i Nūn daḩı
Hidmetiyle buld 1 yolı ey ahsi
74v10 Hidmet èderseñ fetā dèrler saña
Tañrı içün yèler iseñ dört yaña

\subsection{Ahlaklilik}

Fütüvvet yoluna giren bir kişinin en önemli özelliklerinden biri ahlakının temiz olması, iyi ve güzel ahlaklı olmasıdır. Güzel ahlaklı bir kişi, namusuna dikkat eder, kendini şehvetten korur. Şehvetinin esiri olmaz. İffet sahibi olur. İffetli bir kişi ise haya sahibi olmalıdır. Hayalı kişiden çirkin ve kötü davranışlar çıkmaz. Fütüvvet ehli Hz. Peygamber'in "Haya imandandır" hadisini ilke edinir. Ahlaklı kişi iffetli kişidir. İffetin de tövbe ve cömertlik gibi önemli hasleti vardır. Fütüvvet ile tasavvufun ilkeleri birçok alanda örtüşür. İffette nefis temizliği esastır. Tasavvufta da nefis temizliğine önem verilir. (Kâşânî, 1949-1950: 269-270). Emmâre, levvâme, mülhime, mutmainne, râzıye, marziyye ve kâmile'den oluşan ve etvâr-1 seb'a olarak bilinen bir nefis temizleme metodu kullanılır. (Şahin, 2020: 77-96). Bir kişi tövbe ederek, nefsin cimrilik, hırs, dünya sevgisi ve şehvet gibi özelliklerden korunmuş olur.

Ahî Dâ‘̂̂’ye göre ahlaklı olmak için kişi ilk önce şehvetin elinden kurtulmalıdır. Günahlarına tevbe etmeli ve bir daha aynı hataları yapmayacağına söz vermelidir.

4v8 Tevbe ḳ1liñ dèmediñ mi sen bize 
Tevbe ḳılup rāżı oldıḳ bu söze

4v9 Tevbe ḳ1lañ her günehden èr ü gèç

Eyler anı tevbe șuyı hịç hīç

4v10 Kavliñe cümle inandıḳ șılk-1la

Cürm ḳılmaz her kim ol tevbe ḳla

13 r5 Ṭālib-i hạḳ̣ olmaya şehvet-peres

Bala düşüp ḳalmaya hem çün meges

7v15 Bu söze hïuccet dèmişdir Mușțafã

Kim ìmān ḳandaysa andadur ḩayā

\subsection{Bilgelik}

Fütüvvet ehline göre hikmet, bilgeliğin temeli ve dayanağı olarak kabul edilir. Doğruluk da hikmetin temeli ve dayanağıdır. Doğruluk ve hidayet ise hikmetin, bilgeliğin değerleridir. (Kâşânî, 1949-1950: 277-278). İnsanı diğer canlılardan ayıran en temel özelliği akıllı ve iradeli olmasıdır. İnsan aklı ile kendi ihtiyaçlarını karşılar. Aklı ile iyiyi ve kötüyü tespit edip ayırabilir. Doğru olanı bulur ve ona yönelir. Bu sebeple de doğruluk ve hidayetle ilişkilidir. Ahî, hikmetli konuşmalı, hikmetli söze kulak vermeli ve hikmetli söz söyleyen büyüklere tabi olmalıdır. Allah'ın yarattığı her iște hikmet vardır ilkesini benimsemelidir.

Ahî Dâ‘î’ye göre Hz. Musa şeriattir, Hz. Musa’ya rehberlik eden Hızır ise hikmettir. Bu sebeple fütüvvet yoluna giren kişi her işte, Allah'ın sayısız olan hikmetini aramalıdır. Müslüman hikmeti anlayıp ona göre hareket etmelidir. Zira hikmeti kavrayan kişi hidayete erer, doğru yolu bulur.

1v14 Hikmeti çoḳdır Hูudānıñ bī-şumār

Ḩāṣ ḳullar ėdemez cümle şumār

1v6 Hikmetinde kimsene ḳādir degil

Hīç bu fende kimsene māhir degil

44r5 Ṭaş aña dèdi ki yā Mūsā Kelīm

Bunda bir hikmet ḳomışdır ol Kerīm

45r3 Añla imdi ey müsülmān hịmeti

'Āḳıl iseñ țiñlagì1l bu ḳudreti

66v6 Hakḳ hidāyet vèrdi ol günde aña

'Adli yayıldı anıñ hep dört yaña

\subsection{Adaletli olma}

Hak ve hukûka uyma, doğruluktan ayrılmama, hakkaniyetli davranma, hakkını alma, herkesin hakkını gözetme ve hakkını verme adalet ilkesidir. Bir toplumda, kurumda, toplulukta kânun ve nizam yoluyla hakların karşılıklı olarak korunması ve dengeli tutulmasıdır. (Ayverdi, 2010: 10) Abdurrezzak Kâşânî’ye göre ise, "Adalet, bütün üstünlüklerin toplanması ve kuvvetlerin birbirleriyle uyuşması ve uzlaşması yüzünden nefiste hasıl olan vicdanı bir haldir. Bu bakımdan huy üstünlüklerinin en yücesi ve cüvan-mertlik sifatlarının en üstünüdür." (Kâşânî, 1949-1950: 281) Adaletli olmak cömertliğe göre daha yüce kabul edilir. Adaletli kişi zulmetmekle zulme uğramak 
arasında duran kişidir. Fütüvvet eğitimi alan bir kişinin adil olması beklenir. Adil kişi yaratıcının emirlerine uyar. Adalet, insandaki tüm değerleri etkileyerek onların dengeli ve en güzel şekilde yapılmasını sağlar. Adalet olan yerde huzur, olmayan yerde ise kaos vardır. Adaletin vefa ve nasihat gibi değerleri vardır. Ahiliğin ticarette, işçi ve esnaf hakkını gözetmede sergilediği yönetimin temeli hep adalete dayanmıştır. Bu sebeple her işte hak ve hukuku gözeterek adaleti sağlamışlardır. (Kâşânî, 1949-1950: 283-284).

Ahî Dâ‘̂i adalet timsali olarak Hz. Ömer’i örnek verir ve her ahî’nin onun yolunu takip etmesi gerektiğin söyler.

7r12 Adı çıł̣dı ' adl ile ‘ālem țolu

Dād èderdi kim ola kiçi ulu

62r11 Ḥaddi ile olsa işiñ dādı var

Toğrulıḳ ile işiñ bünyādı var

Adalet ehlinin en önemli özelliği vefâlı olmasıdır. Vefalı kişi dostluk ve kardeşliğe önem verir, sadakat kurallarına uyar. Kardeşlerinin hakkını gözetir, onlara ikramda bulunur ve verdiği sözü yerine getirir. Vefalı kişi insanlara cefầ vermez. En vefalı kişi ise Hz. Peygamberdir. Zira EnsarMuhacir kardeşliğinde vefâ göstererek Hz. Ali’yi kardeş olarak seçmiştir.

3v13 Ey seven ḳullara çoḳ ḳılan cefã

Bir cefā yẻrine biñ ḳ1lan vefā

36v12 Hem 'alīyi ḳardaş ètdi Mușțafā

Birbirine eyledi ḩaylī vefā

48r10 Hem aḩ̄ dèdi muhammed Muștafā

Birbirine ḳardaş ètdi bā-vefã

İnsan elest bezminde Allah'a söz vermiştir. Bu sebeple sözüne sadık kalmalıdır. Çünkü söze sadık kalmak bir vefa örneğidir. Vefalı kişi ise yalandan uzak duran kişidir.

45v13 Anda olan 'ahdi key ḳılg̀ıl vefā

Eylemesün ol dahı saña cefã

45v14 Ol elest deminde sen 'ahd eylediñ

'Ahd èdüben belī' dèyü söylediñ

45v15 Sen eger ol 'ahde ḳ1lmazsañ vefã

Eyleye yarın saña çoḳ çoḳ cefā

46r1 Dünyāya geldikde kim ' ahd eyledi

Kim kime vèrdi vü kime söyledi

\subsection{Alçak gönüllülük}

Ahilikteki değerlerden biri de alçak gönüllülüktür. Kişi alçak gönüllü olmalı, kibir ve hasetten uzak durmalıdır. Mütevazi olmalı, büyüklük iddiasında bulunmamalıdır. Kâşânî’ye göre tevazu, "Tevazu, üstünlük ehliyle dostları ve sevgilileri ağırlamak, ululamak, mal ve mevki bakımından kendisinden düşkün, fakat üstünlükte ve yücelikte kendine eş, yahut kendisinden ileri olanları büyük saymak, onları yüceltmek ve kendisinden aşağı bile olsa, münkür olmadıkça, kendisinden aşağı bile olsa herkese, değerini ve mevkiini vermektir." (Kâşânî, 1949-1950: 275). 
Alçak gönüllü kişi korkak değil şecaat gösteren yiğit kişidir. Alçak gönüllü kişi hilim sahibi olur. Hilm sahibi kişi ise kavga ve düşmanlık etmez, ayıplama, kabalık, sertlik ve yobazlık yapmaz. Acı ve belalara karş1 ise sabırlı olur. (Kâş̧ânî, 1949-1950: 275).

Ahî Dâ‘'̂’ye göre alçak gönüllü kişi hilmi ilke edinmeli ve kimse ile tartışmamalıdır.

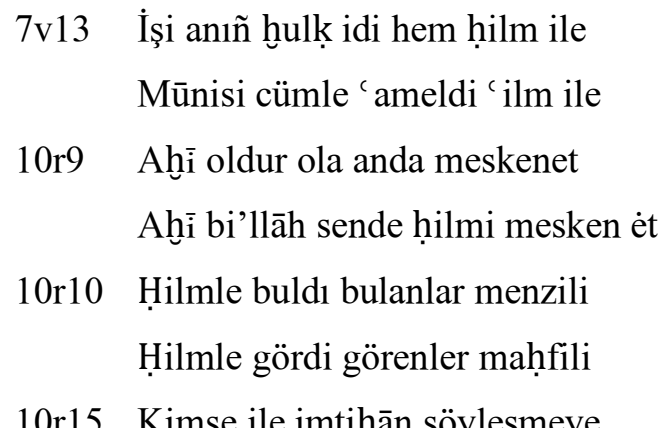

10r15 Kimse ile imtiḥān söyleşmeye

Kimse ile hịç cidāl èdişmeye

74v11 Bir uluya sen de țapış özüñi

Ayagiına țopraḳ eyle yüzüñi

Fütüvvet ehli, tevazuda "velakad kerremnâ benî âdem" düsturunu ilke edinmiștir. Kibirin önüne geçebilmek için, insanın topraktan yaratıldığını vurgulamıştır. Kendisi için istediğini kardeşi için de istemeyi esas kabul etmiştir. Fedakarlığ 1 ve diğergamlığ 1 , kibiri ortadan kaldırmak için ögütlemişlerdir.

\section{Sonuç}

Ahî Dâ‘î fütüvvetnâmesi, bilgelik, doğruluk, cömertlik, kahramanlık, fedakârlık, alperenlik, misafirperverlik, vatan sevgisi, bir tehlikeye karşı birlikte mücadele ve yardımlaşma gibi değerleri içeren bir eserdir. Fütüvvetnâmede geçen bu değerler, ahîlik teşkilatı ile halka öğretilmiş ve halkın eğitimi sağlanmıştır. Bu değerlerin temeli İslam dinine dayanmaktadır. İffet, şecaat, hikmet, adalet ilkeleri İslam ahlakının temelidir. İnsanda değerleri oluşturan etken insanın nefsidir. Nefsin de düşünme, şehvet ve öfke gibi güçleri vardır. Nefsin düşünme gücü ile hikmet, öfke gücü ile cesaret/yiğitlik, şehvet gücü ile de iffet ortaya çıkar. Bu güçler arasındaki dengenin sağlanması ise adalet ile olur. Bu güçlerin dengeli olması ile fazilet, az veya çokluğu ile de rezilet ortaya çıkmaktadır. Ahlâkî eğitimin sağlıklı olabilmesi için nefsin terbiye edilmesi gerekmektedir. Bu sebeple de Ahî Dâ‘î Fütüvvetnâmesi'nde ahlâkî eğitimin temelinde nefis terbiyesi vardır. Doğruluk, tevbe, cömertlik, alçak gönüllülük, vefalı olmak, kardeşine nasihat etmek, doğru yola ulaşması için çalışmak, sabır, dostluk, herkesin hakkını gözetmek, yiğitlik, cesaretlilik, namusluluk gibi temel değerler ahîlik teşkilatı ile halka ögretilmiştir.

Ahî Dâ‘̂̂, eserinde ahilikte uyulan güzel ahlakın ve değerlerin neler olduğunu sade bir dille anlatmıştır. İnsanî, ahlâkî ve manevî değerler bir bütün olarak ve dinî-tasavvufî zeminde ele alınmıştır. Bu değerlerin toplumda birlik ve beraberliği sağlamayı, ortak bir kültür oluşturmayı ve meslek gruplarının aynı ahlakla ahlaklanmasını hedeflemiştir. Ömür boyu süren, bilinçli ve hedefli bir eğitim sistemi olan ahîlik eğitimi yoluyla ahlâkî değerler öğretilerek birey ve toplum kişiliği inşa edilmiştir. Böylece fütüvvetler eliyle toplumda ortak duygu ve düşünce birliği sağlanarak genel kabul gören ilkeler, inançlar ve ahlâkî değerler oluşturulmuştur.

Ahî Dâ‘̂̂, Fütüvvetnâmesi’nde iman, ahlak ve değerleri içeren lirik, öğretici birçok şiir bulunmaktadır. Bu eser, İslamî prensiplere uygun insana saygı temelli, kimseyi dışlamayan, insanları 
manevi açıdan eğitmeyi hedefleyen bir eserdir. Eserde ahlâkî değerlerin öğretilmesinde sık sık ayet ve hadislerden iktibaslar yapmıştır. Bu bağlamda ahlâkî ilkelerin dinî kaynaklara dayandırılması halk üzerinde daha fazla etkili olarak, davranışların içselleştirilmesine katkı sağlamıştır. Kişisel ve meslekî gelişimde özellikle adalet, dürüstlük, doğruluk, sabır, saygı, sevgi, sorumluluk bilinci, vatanseverlik, yardımseverlik, dayanışma gibi değerler teşkilat mensuplarına öğretilmiştir. Bu açıdan bakıldığın da fütüvvetnâmeler, ahlâkî fazilet ve değerlerin öğretildiği, bir yaygın eğitim kurumu olan ahîlik teşkilatının el kitabı hüviyetindedir.

Ahî Dâ‘î Fütüvvetnâmesi’nde hem meslekî eğitimin ilkeleri hem ahlâkî değerler hem de dinî eğitimin aşamaları vardır. Fütüvvetnâmedeki inanç, ahlak, bilgi ve sanat merkezli ilkeler ahîlik teşkilatı eliyle uygulamaya konulmuştur. Buna göre Ahî Dâ'î’nin ilmiyle, inanciyla, mesleğiyle, ahlakıyla, edebiyle tüm yönlerden gelişmiş bir birey yetiştirilmesi hedefinin olduğu görülmektedir.

\section{Kaynakça}

Afshari, M. (2003). Fotovvatnâmehâ va Rasâ'el-e Khâksâriyeh (30 Treatises), Introduction, Compilation \& Explanation by Mehran Afshari, Institute for Humanities and Cultural Studies.

Akçan, K. (2018). Müellifi Bilinmeyen Bir Fütüvvet-nâme (İnceleme-Metin-Dizin), [Yayımlanmamış Yüksek Lisans Tezi]. Akdeniz Üniversitesi Sosyal Bilimler Enstitüsü.

Altuner, N. (1999). "Manzum bir Fütûhnâme, II. Uluslararası Ahilik Kültürü Sempozyumu Bildirileri.

Anadol, C. (1991). Ahilik Kültürü ve Fütüvvet-nâmeler, Kültür Bakanlı̆̆ı Yayınları.

Ankara Üniversitesi, Dil Tarih Coğrafya Fakültesi Kütüphanesi, İsmail Saib I, nu.2883.

Aydın, M. Z.-Güler, Ş. (2012). Okullarda Değerler Ĕ̆itimi, Nobel Yayınc1lık.

Ayverdi, İ. (2010). Asırlar Boyu Tarihî Seyri İçinde Misalli Büyük Türkçe Sözlük (I-III), İstanbul: Kubbealt1 Lugati.

Beyazıt Yazma Eser Kütüphanesi, Veliyyüddin Efendi, nr. 1796, vr.170b-174a.

Bilgin, O. (1992). Şeyh Eşref b. Ahmed Fütüvvet-nâme, Yıldızlar Matbaası.

Ceylan, Ö. (2016). “Attâr'ın Fütüvvetnâmesi İstanbul'da mı...?”, Çukurova Üniversitesi Türkoloji Araştırmalan Dergisi, 1/1, 173-181.

Cin, A-Akçan, K. (2018). 15. Yüzyılda Dâî? Tarafından Yazılmış Manzum Bir Fütüvvetnâme, Mediterranean Journal of Humanities, VIII/1, 101-130.

Cumhur, M. (1978). "Bir Fütüvvetnâme Nüshasının Tanıtımı”, II. Milletlerarası Türk Folklor Bildirileri, IV, 1978, 85.

Çağatay, N. (1990). Ahilik Nedir?, Kültür Bakanlığı Yayınları.

Çatak, A. (2012). Şihâbeddin Sühreverdî Hayatı Eserleri ve Tasavvuf Anlayışı, Gümüşhane Üniversitesi Yayınları.

Debbağoğlu, A. (1979). "Fütüvvet”, Tü̈k Dili ve Edebiyatı Ansiklopedisi, III.

Ekşi, H.-Katılmış, A. (2011). Karakter Eğitimi, Nobel Yayınları.

El-Cevziyye, İbn Kayyım (2017). Medâricu’s-Sâlikîn, çev. Ali Atac, vd. İnsan Yayınları.

Ergül, N. (2013). “Abdurrezzâk Kâşânî (ö.730/1330)'nin Hayatı, İlmî-Tasavvufî̀ Kişiliği ve Eserleri”, Birey ve Toplum, 3/5, 93-125. 
Ertuğrul, Y. (2016). Değerler Ĕgitimi Ĕgitiminde Yeni Ufuklar, 4. Bsk., Akçağ Yayınları.

Fatih Millet Kütüphanesi Ali Emirî, Şeriyye nu.135

Gökçe, İ. (2019). Yahya b. Halil Çoban Birgivî Fütüvvetnâme (İnceleme-Metin-Dizin), Yayımlanmamış Yüksek Lisans Tezi, Erzincan Binali Yıldırım Üniv. Sosyal Bilimler Enstitüsü, Erzincan.

Gölpınarl1, A. (1953-4). "Burgazî ve Fütüvvetnâmesi", Ístanbul Üniversitesi İktisat Fakültesi Mecmuas1, 15/1-4, 76-153.

Gölpınarlı, A. (1949-50). "İslâm ve Türk İllerinde Fütüvvet Teşkilatı ve Kaynakları", İ.Ü. İktisat Fakültesi Mecmuasi, XI/1-4, 3-354.

Gölpınarl1, A. (1955-56). "Șeyh Seyyid Gaybî̀ Oglu S,eyh Seyyid Hüseyin Fütüvvetnâmesi”, Istanbul Üniversitesi Iktisat Fakuiltesi Mecmuast, 17, 1955-1956, 25-155.

Gölpınarlı, A. (2011). İslam ve Türk İlerinde Fütüvvet Teşkilâtı ve Kaynaklan, İstanbul Ticaret Odas1.

Gölpınarlı, A. (1995). "Fütüvvet-nâme-i Sultânî” ve Fütüvvet Hakkında Bazı Notlar", Ístanbul Üniversitesi İktisat Fakültesi Mecmuası, 17/1-4, 127-155.

Gülten, S.-Yılmaz, H. (2014). Fütüvvet-nâme-i Kebîr, Türkiye Yazma Eserler Kurumu Başkanlığ1 Yayınları.

Güneş, M. (2016). Şeyh Eşref b. Ahmed Fütüvvet-nâme Iyilik Kitabı, Gelenek Yayıncılık.

Güngör, E. (1993). Değerler Psikolojisi, Hollanda Türk Akademisyenler Birliği.

Gürel, R. (1992). Razavî’nin Fütüvvet-nâmesi (Fütüvvet-nâme-i Kebir veya Miftâhü'd-dekâyık fî beyâni'l-fütüvveti ve'l-hakâyık), [Yayımlanmamış Doktora Tezi]. Marmara Üniversitesi Sosyal Bilimler Enstitüsü.

İbn Asakir. (1995). Tarihu Dımaşk, Darü'l-Fikr.

Karaismailoğlu, A. (1999). "Hüseyin Vâiz-i Kâş̧ifi”", DIA, 19, TDVY.

Kâşânî, A. (1949-1950). Tuhfetü'l-İhvân, Terc: Abdülbâki Gölpınarlı, İslâm ve Türk İllerinde Fütüvvet Teşkilatı ve Kaynakları, İstanbul Üniversitesi İktisat Fakültesi Mecmuası, C.11, Ekim 1949-Temmuz 1950, No.1-4, s.277-279.

Keskin, Y. (2016). Değerler Ĕ̆itimi Yaklaşımları, Teoriden Pratiğe Değerler Eğitim, ed. Mustafa Köylü, Nobel Akademik Yayıncılık.

Köksal, M. F. (2019). Manzum Fütüvvetnâme, Türkiye Bilimler Akademisi.

Köprülü, M. F. (1947). “Anadolu Selçuklularının Yerli Kaynakları”, Belleten, VII, 1947, 445-446.

Küçük, S. (2000). “Abdullah Ensârî el-Herevî’nin Tasavvufî Fütüvvet Risâlesi: "Kitabu'lFütüvvet”, Sakarya Üniversitesi Illahiyat Fakültesi Dergisi, 2/2000.

Levend, A. S. (1963). "Ümmet Çağında Ahlâk Kitaplarımız”, Türk Dili Araştırmaları Yıllı̆̆gBelleten, 234, 1963, 89-115.

Meriç, N. (2013). Radavi’nin Haza Kitabu Fütüvvetnâme (Manisa Il Halk Kütüphanesi 45HK1137/7), [Yayımlanmamış Yüksek Lisans Tezi]. Celal Bayar Üniversitesi Sosyal Bilimler Enstitüsü.

Millet Kütüphanesi, Hekimoğlu Ali Paşa Kütüphanesi, Nr. 479, v.99a-16b.

Milli Kütüphane, Yazmalar, No: 8602/1.

www.turkishstudies.net/religion 
Ocak, A. Y. (1996). "Fütüvvet", DİA, 13, TDVY.

Ocak, A. Y. (1996). "Fütüvvetnâme", DiA, 13, TDVY.

Oğuzhan, F. (1991). Eğitim Terimleri Sözlüğ̈̈, TDK Yayınları.

Orhan, K. Z. (2016). Alâüddevle Simnânî ve Tasavvufî Görüşleri, [Yayımlanmamış Doktora Tezi]. Marmara Üniversitesi Sosyal Bilimler Enstitüsü.

Pırlanta, İ. (2017). Fütüvvet, Ahilik ve Loncalar, Islâm Kurumları Tarihi, ed. Eyüp Baş, Grafiker Yayınları.

Sarkkaya, M. S. (2007). "Ahiliğin Dünya Görüşü ve Bunu Oluşturan Dînî-Ahlakî Değerler”, Arayışlar İnsan Bilimleri Araştırmalanı, 17, 1-13.

Sarıaya, M. S. (2008). Fütüvvetnâme-i Câfer Sâdık İnceleme-Metin, Horasan Yayınları.

Sarkkaya, M. S. (2002). XIII-XVI. Asirlardaki Anadolu'da Fü̈üvvetnâmelere Göre Dinî Inanc, Motifleri, Türk Tarih Kurumu Basımevi.

Sarıkaya, M. S. (1999). “Osmanlı Devleti'nin İlk Asırlarında Toplumun Dini Yapısına Ahilik Açısından Bir Bakış Denemesi”, Süleyman Demirel Üniversitesi İlahiyat Fakültesi Dergisi, $6,1-14$.

Sülemî, Ebu Abdi'r-Rahman Muhammed İbn el-Hüseyn. (1977). Tasavvufta Fütüvvet, Çev. Süleyman Ateş, A. Ü. İlahiyat Fakültesi Yayınları.

Süleymaniye Kütüphanesi, Ayasofya, 2049, vr.159-181.

Şahin, M. (2020). Etvâr-1 Seb‘a Geleneği ve Vâhib Ümmî’de Etvâr-1 Seb‘a, Turkish StudiesComparative Religious Studies, 15/1, 77-96.

Tepe, H. (2002). Değer ve Değerler Bilgisi, Vadi Yayınları.

Topak, M. (2016). Ahî Dâ'î ve Türkçe Manzum Eseri: Fütüvvetnâme-i Tarsûsî (İnceleme-Metin), [Yayımlanmamış Yüksek Lisans Tezi]. Çukurova Üniversitesi Sosyal Bilimler Enstitüsü.

Torun, A. (1998). Türk Edebiyatında Türkçe Fütüvvetnâmeler, Kültür Bakanlığı Yayınları.

Uludağ, S. - Ocak, A. Y. (1996). "Fưtüvvet", DIA, 13, TDVY, 259- 263.

Uludağ, S. (2002). "Kâşânî, Abdürrezzâk”, DİA, 25, TDVY, 5-6.

Yeniterzi, E. (2001). “Türk Edebiyatında Manzum Fütüvvetnâmeler”, Konya Postası-Akademik Sayfalar, 3/3-173, 321-323.

Yılmaz, K. (2006). Burgazî Fütüvvetnâme Dil İncelemesi-Metin-Sözlük, [Yayımlanmamış Yüksek Lisans Tezi]. Sakarya Üniviversitesi Sosyal Bilimler Enstitüsü.

Yörükoğlu, A. (1998). Çocuk Ruh Să̆ğı̆̆, Özgür Yayıncıllk. 